\title{
A COHORT STUDY ON SHIGA TOXIN PRODUCING E. COLI O157:H7 ISOLATED FROM SOME MEAT PRODUCTS IN ASSIUT GOVERNORATE AS A CAUSE OF BLOODY DIARRHEA IN CHILDREN
}

\author{
RAAFAT HASSANEIN ${ }^{* * * *}$; SOHAILA F.H. ELHAWARY ${ }^{* * *} ;$ K. IBRAHIM ELSAYH ${ }^{* * * *}$ and \\ ASMAA A. A. HUSSEIN ${ }^{* *}$ \\ *Department of Laboratory Medicine, College of Applied Medical Sciences, Umm Al-Qura University, Makkah, Saudi \\ Arabia. \\ ${ }^{* *}$ Department of Animal Hygiene and Zoonoses, Faculty of Veterinary Medicine, Assiut University, Egypt. \\ ${ }^{* * *}$ Animal Health Research Institute, Assiut Branch, Egypt. \\ ${ }^{* * * *}$ Department of Pediatric, Faculty of Medicine; Assiut University, Egypt.
}

Email: sfhaae@yahoo.com

Assiut University web-site: www.aun.edu.eg

\section{ABSTRACT}

Received at: 3/8/2015

Accepted: 7/9/2015
The present study was conducted to investigate the presence of $E$. coli especially $E$. coli $\mathrm{O} 157: \mathrm{H} 7$ and to detect the presence of the stx 1 and stx 2 genes in isolates derived from a total of 80 samples including 20 samples each of frozen beef burgers, frozen sausages, beef burger sandwiches and sausage sandwiches. The samples were randomly collected from retail supermarkets and restaurants in Assiut, Egypt. In addition, 20 stool cultures collected from hospitalized children admitted in Assiut Pediatric University Hospital with history of diarrhea or fever. E. coli was detected in $9(45 \%), 6(30 \%), 1(5 \%), 1(5 \%)$ and $12(60 \%)$ of frozen beef burgers, frozen sausages, beef burger sandwiches, sausage sandwiches and children stool samples, respectively. E. coli $\mathrm{O} 157$ was detected in eleven of the $100(11 \%)$ samples tested (two from frozen beef burgers, three from frozen sausages, one from each of beef burger sandwiches and sausage sandwiches and four from children stool samples). Whereas $\mathrm{H} 7$ gene was not detected in all E. coli $\mathrm{O} 157$ positive samples, but, the genes stx 1 and stx2 were detected in two E. coli $\mathrm{O} 157$ isolates obtained from two frozen sausage samples. The public health significance of this pathogen and consumer's safety were discussed.

Key words: Escherichia coli, E. coli O157:H7, shiga toxin, beef burgers, sausages, and children stools

\section{INTRODUCTION}

The microbiological safety of meat products is an important public health concern. Numerous epidemiological reports have identified pathogenic $E$. coli, particularly E. coli $\mathrm{O} 157: \mathrm{H} 7$, as major cause of disease outbreaks associated with contaminated meat (Olsvik et al., 1991; Meng and Doyle, 1998).

The strains of enterohemorrhagic E. coli (EHEC) are a subset of the Shiga-toxin-producing E. coli (STEC) strains that cause disease in humans and pose a threat to public health worldwide (Griffin, 1995). The serogroup $\mathrm{O} 157$ and $\mathrm{O} 157: \mathrm{H7}$, in particular, have caused a number of human infections, through the consumption of foods of animal origin, particularly those originating from cattle, e.g., minced/comminuted beef (Williams et al., 2005). The pathogenicity of $E$. coli $\mathrm{O} 157$ and $\mathrm{O} 157: \mathrm{H} 7$ including STEC is associated with several virulence factors. The main factor contributing to their pathogenicity is their capacity to produce two potent phage-encoded cytotoxins called Shiga-toxins (namely, Stx1 and Stx2). Shiga-toxins cause disease, such as hemorrhagic colitis (HC) and hemolytic uremic syndrome (HUS), through cytopathic effects on the vascular endothelial cells of the kidneys, intestines, the central nervous system, and other organs. In addition to the production of toxins, another virulence-associated factor expressed by STEC is a protein called intimin, which is encoded by the eae gene and is responsible for the intimate attachment of the STEC to the intestinal epithelial cells. This further causes attaching and effacing lesions in the intestinal mucosa (Garrido et al., 2006).

In 1982, E. coli O157 was first identified as a foodborne pathogen found in contaminated hamburger (Riley and Remis, 1983). Cattle and other ruminants have been established as the major natural reservoir for E. coli O157 (Rassmussen et al., 1993) and thus play a significant role in the epidemiology of human infections (Griffin and Tauxe, 1991). Many environmental and food-borne sources have caused $E$. 
coli 0157 infections in humans through either consumption of food that is bovine in origin (Slutsker et al., 1988).

In 2007, the incidence of O157 and non- O157 STEC infections in the United States was 1.19 and 0.59 per 100,000 people, respectively (Centers for Disease Control and Prevention, 2009). The incidence of STEC infections in the European Union in 2006 and 2007 was 1.1 and 0.6 per 100,000 respectively (European Food Safety Authority (EFSA, 2009). About $70 \%$ of cases with human STEC infection in the U.S. and $50 \%$ in the E.U. were attributed to STEC O157 (EFSA, 2009). Besides the O157 serotype, in 2005 about 400 serotypes of STEC were known to be associated with illness in humans as agents of diarrhea, HC and HUS (Scheutz and Strockbine, 2005). In the light of the foregoing, this study therefore aimed at determining the presence of both E. coli and E. coli O157:H7 in raw and ready-to- eat (RET) meat products and children stool in Assuit Governorate, and to detect the harborage of stx 1 and stx2 genes using the polymerase chain reaction (PCR).

\section{MATERIAL and METHODS}

\section{Collection of samples:}

The food samples examined were obtained from different supermarkets and shops selling ready-to-eat meat in Assiut Governorate. The samples were grouped in three categories. The first category consisted of 40 frozen meat product samples (20 samples each of beef burgers and sausages). The second category consisted of 40 thermally processed sandwiches (20 samples each of beef burgers and sausages). The third category consisted of 20 stool samples collected from diarrheic children from different clinical laboratories and hospitals in Assiut Governorate. Samples were transferred directly without delay to the laboratory in an ice box for bacteriological examination.

\section{Preparation of samples:}

At the laboratory, fresh samples were processed upon delivery. The frozen samples were thawed by overnight refrigeration; each sample was aseptically and carefully freed from its casing and mixed thoroughly in sterile mortar.

Bacterial isolation (De Boor and Heuvelink, 2000):

\section{Selective enrichment:}

For enrichment, Ten grams of each meat product samples as well as swabs from children stools were aseptically added to 90 milliliters of modified Tryptic Soya Broth (TSB/CM129, Oxoid, UK) supplemented with $20 \mathrm{mg} / \mathrm{L}$ Novobiocin (Sigma, Germany). The meat samples were homogenized into a stomacher bag for at least $2 \mathrm{~min}$. into a stomacher (Colworth, 400 ) and then they were incubated at $37^{\circ} \mathrm{C}$ for $24 \mathrm{~h}$.

\section{Selective plating:}

Loopful from the incubated broth was streaked onto the surface of Eosin Methylene Blue agar (EMB) (Oxoid, CM69) to presumptively identify isolates as Gram-negative enteric bacteria and presumptive $E$. coli (green-metallic colonies), and onto Sorbitol MacConkey agar (SMAC) (Oxoid, CM813) to test for sorbitol non-fermenting bacteria (colorless colonies). After 18 to $24 \mathrm{~h}$ at $37^{\circ} \mathrm{C}$, characteristic colonies from EMB agar and SMAC agar were transferred onto Trypticase Soy agar (TSA) (Oxoid CM131) for further identification.

\section{Identification of isolates:}

Isolated purified strains were identified morphologically by Gram's stain and biochemically confirmed as E. coli according to Varnam and Evans (1991) by the conventional IMViC, Urea hydrolysis, Triple sugar iron agar and fermentation of sugars (sorbitol).

Serological identification of $\boldsymbol{E}$. coli $\mathbf{O 1 5 7 : H 7}$ (Chan et al., 2005):

The biochemically identified non sorbitol fermenting colonies from SMAC were subjected to slide agglutination with the E. coli O157 latex test kit (Oxoid, DR620 M) and the agglutinating colonies were further processed for definite confirmation.

\section{PCR assay:}

Target genes and oligonucleotide sequences used for PCRs are listed in Table 1, and three pairs of primers were chosen according to (Radu et al., 2000). The suspected bacterial colony was subcultured onto TSB and incubated overnight at $37^{\circ} \mathrm{C}$ for DNA extraction according to manufacturer's instructions (QIAGEN Lot No. 136243308). PCR reactions were performed with Thermal cycler (Biometra,T professional) using a total volume of $25 \mu \mathrm{l}$. The optimal amplification reaction mixture contained $12.5 \mu$ l of master mix, $1 \mu \mathrm{l}$ of forward primer $(10 \mathrm{pmol}), 1 \mu \mathrm{l}$ of reverse primer (10 pmol), $7 \mu \mathrm{l}$ of template DNA, $3.5 \mu \mathrm{l}$ of nucleasefree water. Go Taq ${ }^{\circledR}$ Green Master Mix is a premixed ready-to-use solution (Promega, USA):608-274 4330).

The PCR samples were subjected to amplification according to the following program: initial denaturation at $94^{\circ} \mathrm{C}$ for $5 \mathrm{~min}$. and then 40 cycles comprising denaturation at $94^{\circ} \mathrm{C}$ for 40 seconds, annealing at $50^{\circ} \mathrm{C}$ for 40 seconds; and an extension at $72^{\circ} \mathrm{C}$ for $1 \mathrm{~min}$. Following this, a final extension at $72^{\circ} \mathrm{C}$ for 5 minutes was carried out. The electrophoresis products were visualized by UV transilluminator (Biometra) and photographed by Gel Documentation System including BioDocAnalyze (BDA) Software (Biometra) for measuring and analyzing the PCR results. 
Table 1: Primers used to amplify fragments of genes responsible for expression of different virulence factors genes and a species specific gene for $E$. coli

\begin{tabular}{ccc}
\hline Target gene & Primer sequence & Amplicon product (bp) \\
\hline & SLTIR5'CAGTTAATGTGGTGGCGAAGG-3' & \\
SLT-I & SLTIF5'CACCAGACAATGTAACCGCTG-3' & 384 \\
\hline & SLTIIR5'ATCCTATTCCCGGGAGTTTACG-3' & \\
SLT-II & SLTIIF5'GCGTCATCGTATACACAGGAGC-3' & 584 \\
\hline & FLICH7R5'GCGCTGTCGAGTTCTATCGAGC-3' & \\
FlicH7 & FlicH7F5'CAACGGTGACTTTATCGCCATTCC-3' & 625 \\
\hline
\end{tabular}

RESULTS

The obtained results are recorded in Tables 2- 4 and Fig. 1\&2

Table 2: Isolation rate of E. coli from different meat product and children stool samples.

\begin{tabular}{cccc}
\hline \multirow{2}{*}{ Type of samples } & \multirow{2}{*}{ No. of examined samples } & \multicolumn{2}{c}{ Positive samples } \\
\cline { 3 - 4 } & 20 & No. & \% \\
\hline Frozen beef burgers & 20 & 6 & 45 \\
\hline Frozen sausages & 20 & 1 & 30 \\
\hline Cooked beef burgers & 20 & 1 & 5 \\
\hline Cooked sausages & 20 & 12 & 60 \\
\hline Children stools & 100 & 29 & 29 \\
\hline Total & &
\end{tabular}

Table 3: Incidence of E. coli $\mathrm{O} 157$ in different meat product and children stool samples by Latex Agglutination test.

\begin{tabular}{cccc}
\hline \multirow{2}{*}{ Type of samples } & \multirow{2}{*}{ No. of examined samples } & \multicolumn{2}{c}{ Positive samples } \\
\cline { 3 - 4 } & 20 & No. & $\%$ \\
\hline Frozen beef burgers & 20 & 3 & 10 \\
\hline Frozen sausages & 20 & 1 & 15 \\
\hline Cooked beef burgers & 20 & 1 & 5 \\
\hline Cooked sausages & 20 & 4 & 20 \\
\hline Children stools & 100 & 11 & 11 \\
\hline Total &
\end{tabular}

Table 4: Characterization of E. coli O157 virulence factors (SLT1 \& SLT2) and flagellar (H7) genes by PCR from different samples.

\begin{tabular}{|c|c|c|c|c|c|c|c|c|c|}
\hline \multirow[t]{2}{*}{ Type of samples } & \multirow{2}{*}{$\begin{array}{c}\text { No. of } \\
\text { samples }\end{array}$} & \multicolumn{2}{|c|}{ No. of $E$. coli 0157} & \multicolumn{2}{|c|}{$\begin{array}{l}\text { SLtx-I contain } \\
\text { isolates }\end{array}$} & \multicolumn{2}{|c|}{$\begin{array}{l}\text { SLtx-II contain } \\
\quad \text { isolates }\end{array}$} & \multicolumn{2}{|c|}{ H7 gene } \\
\hline & & No. & $\%$ & No. & $\%$ & No. & $\%$ & No. & $\%$ \\
\hline Frozen beef burgers & 20 & 2 & 10 & - & - & - & - & - & - \\
\hline Frozen sausages & 20 & 3 & 15 & 1 & 5 & 1 & 5 & - & - \\
\hline Cooked beef burgers & 20 & 1 & 5 & - & - & - & - & - & - \\
\hline Cooked sausages & 20 & 1 & 5 & - & - & - & - & - & - \\
\hline Children stools & 20 & 4 & 20 & - & - & - & - & - & - \\
\hline Total & 100 & 11 & 11 & 1 & 1 & 1 & 1 & 0 & 0 \\
\hline
\end{tabular}




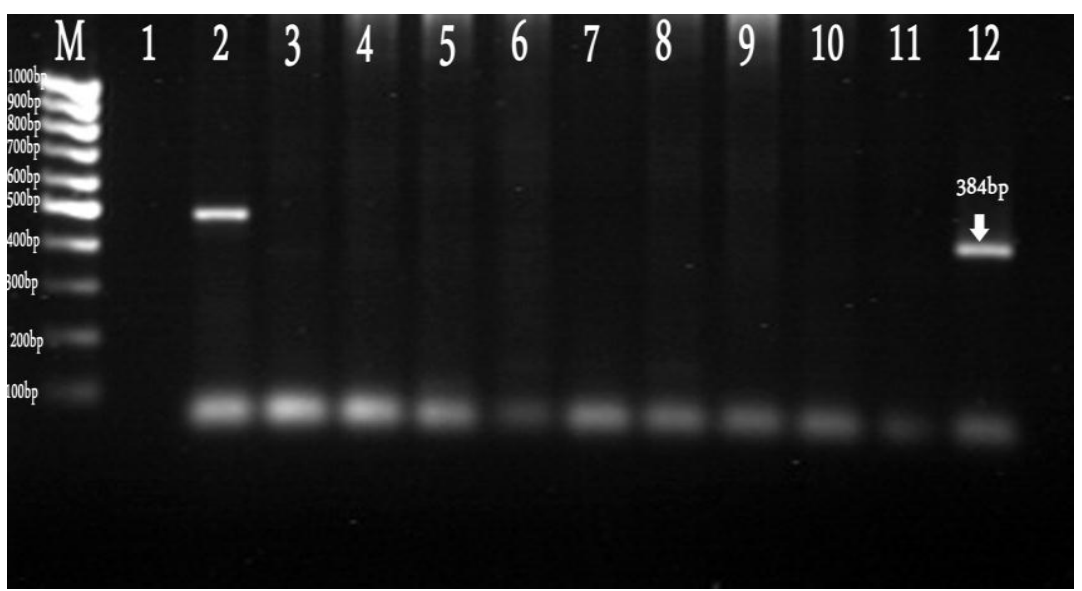

Figure (1): PCR products of Shiga toxin I (stx-I) on agarose gel 2\% stained by Etbr. Lane M: 100bp DNA ladder; Lane 1: Negative control; Lane 2-11: Negative E. coli O157 for Shiga toxin I production; Lane 12: Shiga toxin I gene-positive strains isolated from frozen sausage samples.

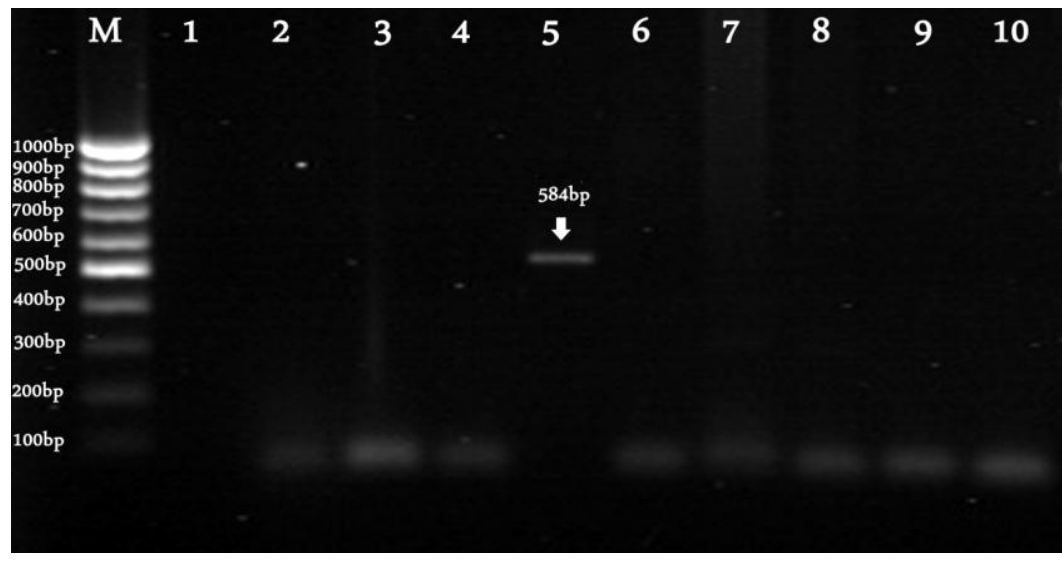

Figure (2): PCR products of Shiga toxin II (stx-II) on agarose gel 2\% stained by Etbr. Lane M: 100bp DNA ladder; Lane 1: Negative control; Lane 2-4 \& 6-10: Negative E. coli O157 for Shiga toxin II production; Lane 5: Shiga toxin II gene-positive strains isolated from frozen sausage samples.

\section{DISCUSSION}

Because the reservoir of $E$. coli is the intestinal tract of both man and animals, the presence of such organism in foods and water is used as indicator of faecal pollution either directly or indirectly (ICMSF, 1978).

A total of 80 frozen and cooked beef burger and sausage samples as well as 20 children stool samples were analyzed and determined the levels of $E$. coli in the examined samples. According to the data in Table (2), Twenty nine E. coli strains were isolated, resulting in an overall prevalence of $29 \%$. The highest isolation frequencies of $E$. coli among the different samples were from children stools $(60 \%)$, frozen beef burgers $(45 \%)$, frozen sausages $(30 \%)$, with lower isolation frequencies from cooked beef burgers and cooked sausages (5\% for each product). Regarding frozen sausage, similar results $(30 \%)$ was obtained by Badri et al. (2009) in Casablanca. While lower levels were obtained in Egypt by Hassanien
(2004), who showed that, $20 \%$ of frozen sausage and $12 \%$ of frozen beef burgers were contaminated with E. coli. In Iran Kalantari et al. (2012) detected E. coli in $14(10.5 \%)$ of sausage sandwich samples and in 22 $(16.4 \%)$ of hamburger sandwich samples. On the other hand, E. coli was isolated from children stool with a percentage higher than that isolated by Ali et al. (2010) who isolated E. coli with a percentage of $7.14 \%$ from cases of acute diarrhea.

The differences in contamination levels could be affected by the national or geographic characteristics of meat sources, processing environments, and different methodologies such as numbers, amounts and periods of samples tested (Kegode et al., 2008).

A number of reports from different countries report the presence of E. coli $\mathrm{O} 157$ isolates in a variety of foods of domestic animal origin. In Turkey, Noveir et al. (2000) reported that $0.4 \%$ of the 225 ground beef, $2 \%$ of the 50 hamburger, $1 \%$ of the 101 sausage samples were contaminated with $E$. coli O157. In a 
study reported by Silveira et al. (1999) concerning the investigation of E. coli $\mathrm{O} 157$ in Brazil, 886 hamburger samples were negative. Chinen et al. (2001) reported that $4.8 \%$ of 83 fresh pork sausage and $3.3 \%$ of 30 dry sausage samples examined in Argentina were contaminated with E. coli $\mathrm{O} 157$.

March and Ratnam, (1989) and Silveira et al. (1999) stated that the latex test is simple, highly efficient and reliable test in detecting E. coli $\mathrm{O} 157: \mathrm{H} 7$ with $100 \%$ sensitivity and specificity. The current study showed that eleven $(11 \%)$ of the 100 samples of different meat product and children stool were contaminated with $E$. coli $\mathrm{O} 157$ (Table 3). The prevalence of this organism was frequently higher in children stools $(20 \%)$, frozen sausages $(15 \%)$ and frozen beef burgers $(10 \%)$, with lower isolation frequencies from cooked beef burgers and cooked sausages (5\% for each product). Regarding frozen beef burgers, these findings corroborate those of Mattar and Vasquez (1998) who reported that $8.7 \%$ of hamburger samples tested were contaminated with E. coli O157 in Colombia. Also, this result closely agrees with a previous study of Keles et al. (2006) in which E. coli O157 was isolated from frozen hamburger balls with an isolation rate of $12 \%$ in Turkey. In the present study, the incidence of $E$. coli $\mathrm{O} 157$ in frozen sausage was higher than those reported by Nastasijevic et al. (2009) in Serbia (2.1\%) and in Egypt, Abd El-Atty and Meshref (2007) reported a prevalence of $2 \%$ in sausage. Our incidence of E. coli $\mathrm{O} 157$ in frozen sausage corroborate those of Beneduce et al. (2008) since both fall within a similar percentage range. The presence of E. coli $\mathrm{O} 157$ in sausage was attributed to contamination from faeces of infected animals as well as the unsatisfactory hygienic measures during manufacturing and handling (Abd El-Atty and Meshref, 2007). The result of the current study regarding to the incidence of E. coli $\mathrm{O} 157$ in children stool was higher than those reported by Hassanein et al. (2012) and Abd Al-Azeem et al. (2013) who isolated the bacterium from (1.7\%) and (13.3\%) from human patients with diarrhea. Most significant of this study is the fact that E. coli $\mathrm{O} 157$ was isolated from ready to eat beef burgers and sausages samples. Contamination by this organisms therefore could be as a result of improper handling of the product after preparation and most especially from vectors like flies and hands of the sellers themselves.

STEC infections in humans are primarily regarded as food-borne, and numerous outbreaks have been attributed to consumption of STEC contaminated foodstuff (Mead et al., 1999; Rangel et al., 2005 and (EFSA), 2009). Food may become contaminated with STEC at all stages of production and retail but in most cases the source of STEC in foodstuff remains unknown (Mead et al., 1999; (CDC), 2009 and (EFSA), 2009).
In this study, 11 E. coli 0157 isolates were characterized by PCR technique and the virulence factor coding genes were detected. Sltx-1 gene was detected in one out of the three frozen sausage isolates; also, Sltx-2 gene was detected in one out of the three frozen sausage isolates (Table 4, Figure $1 \& 2)$. Similar occurrences were observed in studies conducted by Beneduce et al. (2008) who confirmed two isolates by molecular methods as shiga toxinproducing E. coli O157. Conversely, Tafida et al. (2014) reported the detection of stx 1 gene in 2 out of the 4 E. coli $\mathrm{O} 157$ isolates tested by PCR; but stx 2 was not detected in any of the isolates tested.

Although E. coli $\mathrm{O} 157: \mathrm{H} 7$ is the predominant E. coli incriminated in food borne disease, various nonmotile 0157 variants have been isolated (Feng et al.,1998). None motile variant of the O157 serotype have been isolated more frequently worldwide, some have been implicated in illness and theses variant designated (non-motile) NM or H- (Aleksic et al., 1992). E. coli O157:H7 and E. coli O157: H- (nonmotile) continue to be the dominant causes of illness in humans, from the numerous VTEC serotypes identified (Feng, 1993). In this study, none of E. coli $\mathrm{O} 157$ was found to harbor $\mathrm{H} 7$ genes (Table 4). These findings corroborate those of Sarimehmetoglu et al. (1998) and Noveir et al. (2000) who found that none of the isolates was characterized as $\mathrm{H} 7$ strain.

It is important to realize that management of meat safety risks should be based on an integrated effort and approach that applies to all sectors, from the producer through the processor, distributor, packer, retailer, food monitoring authorities and consumer. The report of the presence of E. coli $\mathrm{O} 157$ in this study should prompt relevant authorities to bear in mind that most food borne illnesses may be due to mishandling of foods, while animal-borne pathogens introduced into the environment lead to illness associated with consumption of contaminated meat. Thus, consumer education and environmental pollution issues should be major targets in efforts to improve meat and food safety.

\section{REFERENCES}

Abd El-Atty, N.S. and Meshref, A.M.S. (2007): Prevalence of Salmonella and E. coli $\mathrm{O} 157$ in some foods. Beni-Suef Vet. Medicine Journal, $5^{\text {th }}$. Scientific Conference: 73-78.

Abd Al-Azeem, M.W.; Hussein, A.A. Asmaa; Sultan, S. and Mohamed, W.K. (2013): Microbiological and Molecular Studies on $E$. coli $\mathrm{O} 157: \mathrm{H} 7$ as one of Important Food Borne Disease. XX International Congress of Mediterranean Federation of Health and Production of Ruminants, 19-22 February, Assiut University, Egypt: 13-22.

Ali, S.F.H.; Hassanein, R.; Abd El-Malek, A.M. and El-Sayh, K.I. (2010): Incidence and 
characterization of E. coli $\mathrm{O} 157: \mathrm{H} 7$ isolated from minced beef, chicken meat and human stools in Assiut city. Assiut Vet. Med. J., 56.125 .

Aleksic, S.; Karch, H. and Bockemuhl, J. (1992): A biotyping scheme for shiga-like toxin producing E. coli $\mathrm{O} 157$ and list of serological cross reaction between $\mathrm{O} 157$ and other gram negative bacteria. Zbl. Bak., 276: 221-230.

Badri, S.; Filliol, I.; Carle, I.; Hassar, M.; Fassouane, A. and Cohen, N. (2009): Prevalence of virulence genes in Escherichia coli isolated from food in Casablanca (Morocco). Food Control, 20: 560-564.

Beneduce, L.; Spano, G.; Nabi, A.Q.; Lamacchia, F.; Massa, S.; Aouni, R. and Hamama, A. (2008): Occurrence and characterization of Escherichia coli $\mathrm{O} 157$ and other serotypes in raw meat products in Morocco. J. Food Prot., 71 (10): 2082-2086.

C.D.C. "Centers for Disease Control and Prevention" (2009): Food Net 2007 Surveillance Report. CDC, Atlanta, US.

Chan, E.; Ball, L. and Horsman, G.B. (2005): Comparison of four latex for detection of $E$. coli O157. Clin. Lab. Sci., 11(5): 266-268.

Chinen, I.; Tanaro, J.D. and Miliwebsky, E. (2001): Isolation and characterization of Escherichia coli $\mathrm{O} 157$ from Argentina. J. Food Prot., 64: 1346-1351.

De Boor, E. and Heuvelink, A.E. (2000): Methods for the detection and isolation of shiga-toxin producing E. coli. J. Appl. Microbiol. Symposium supplement, 88: 133-143.

EFSA "European Food Safety Authority" (2009): The community summary report on trends and sources of zooneses and zoonotic agents in the European Union in 2007. The EFSA Journal: 1-128.

Feng, P. (1993): Identification of E. coli serotype O157:H7 by DNA probe specific for allele of uidA gene. Mol. Cell. Probes., 7: 151-154.

Feng, P.; Lampel, K.A.; Karch, H. and Whittam, T.S. (1998): Grenotypic and phenotypic changes in the emergence of E. coli O157:H7. J. Infect. Dis., 177: 1750-1753.

Garrido, P.; Blanco, M.; Moreno-Paz, M.; Briones, C.; Dahbi, G. and Blanco, J.E. (2006): STECEPEC oligonucleotide microarray: A new tool for typing genetic variants of the LEE pathogenicity island of human and animal Shiga toxin-producing Escherichia coli (STEC) and enteropathogenic E. coli (EPEC) strains. Clinical Chemistry, 52: 192-201.

Griffin, P.M. (1995): Symposium on new and emerging pathogens: E. coli O157:H7-beyond the burger. In: Abstracts of the $35^{\text {th }}$ Interscience.

Griffin, P.M. and Tauxe, R.V. (1991): The epidemiology of infections caused by
Escherichia coli O157:H7, other enterohemorrhagic E. coli and the associated hemolytic uremic syndrome. Epidemiologic Reviews, 13: 60-98.

Hassanien, Fatin, S. (2004): Bacterial hazards associated with consumption of some meat products. Benha Vet. Med. J., 15 (2): 41-54.

Hassanein, R.; Hussein, A.A. Asmaa; Sayed, S.M. Amal and Ahmed, M.L. (2012): Escherichia coli $\mathrm{O} 157: \mathrm{H} 7$ as an emerging foodborne zoonotic pathogen. J. Egypt. Vet. Med. Assoc., 72: 269-283.

ICMSF "International Commission on Microbiological Specification for Foods" (1978): Microorganisms in foods, their significance and methods of enumeration. $2^{\text {nd }}$ ed. Uni. Of Toronto Press, Toronto.

Kalantari, S.; Sepehri, G.; Bahrampour, A. and Sepehri, E. (2012): Determination of bacterial contamination isolated from Sandwiches in Kerman City and their resistance to commonly used antimicrobials. Archives of Applied Science Research, 4 (2): 1100-1105

Kegode, R.B.; Doetkott, D.K.; Khaitsa, M.L. and Wesley, I.V. (2008): Occurrence of Campylobacter species, Salmonella species and generic Escherichia coli in meat products from retail outlets in the Fargo metropolitan area. J. Food Safety, 28: 111-125.

Keles, A.; Ucar, G. and Guner, A. (2006): Investigation on the presence of $E$. coli O157:H7 in inegol and hamburger meat balls. Vet. Bil. Derg., 22, 1-2: 51-57.

March, S.B. and Ratnam, S. (1989): Latex Agglutination test for Detection of Escherichia coli Serotype O157. J. Clinc. Microbiol., 27(7): 1675-1677.

Mattar, S. and Vasquez, E. (1998): Escherichia coli O157:H7 in Colombia. Emerg. Infect. Dis., 4: 126-127.

Mead, P.S.; Slutsker, L.; Dietz, V.; McCaig, L.F.; Bresee, J.S.; Shapiro, C.; Griffin, P.M. and Tauxe, R.V. (1999): Food-related illness and death in the United States. Emerging Infectious Diseases, 5: 607-625.

Meng, J. and Doyle, M.P. (1998): Emerging and evolving microbial food-borne pathogens. Bulletin de L'Institut Pasteur, 96: 151-164.

Nastasijevic, I.; Mitrovic, R. and Buncic, S. (2009): The occurrence of Escherichia coli $\mathrm{O} 157$ in/on faeces, carcasses and fresh meats from cattle. Meat Sci., 82: 101-105.

Noveir, M.R.; Dogan, H.B. and Halkman, A.K. (2000): A note on Escherichia coli $\mathrm{O} 157: \mathrm{H} 7$ serotype in Turkish meat products. Meat Sci., 56: 331-335.

Olsvik, O.; Wasteson, Y.; Lund, A. and Hornes, E. (1991): Pathogenic Escherichia coli found in food. Int. J. Food Microbiol., 12: 103-113. 
Radu, S.; Rusul, G.; Ling, O.W. (2000): Rapid isolation and detection of E. coli $\mathrm{O} 157: \mathrm{H} 7$ by use of Rainbow agar O157TM and PCR assay Southeast Asian J. Trop. Med. Public Health., 31(1).

Rangel, J.M.; Sparling, P.H.; Crowe, C.; Griffin, P.M. and Swerdlow, D.L. (2005): Epidemiology of Escherichia coli O157:H7 outbreaks, United States, 1982-2002. Emerging Infectious Diseases, 11: 603-609.

Rassmussen, M.A.; Cray, W.C.; Casey, T.A. and Whip, S.C. (1993): Rumen content as a reservoir of enterohemorrhagic E. coli. FEMS Microbiology Letters, 114: 79-84.

Riley, L.W. and Remis, R.S. (1983): Hemorrhagic colitis associated with a rare E. coli serotype. New England Journal of Medicine, 308: 681685.

Sarimehmetoglu, B.; Kuplulu, O. and Kaymaz, S. (1998): Hamburger ve inegöl köftelerinden Escherichia coli O157:H7 izolasyonu. Ankara Üniv Vet. Fak. Derg., 45: 221-227.

Scheutz, F. and Strockbine, N.A. (2005): Genus I Escherichia. In: Garrity, G.M.; Brenner, D.J.; Krieg, N.R. and Staley, J.T. (Eds). Bergey's
Manual of Systematic Bacteriology. Springer, pp: 607-624.

Silveira, N.T.; Silva, N.; Contreras, C.; Mitagusku, L.; Baccin, M. L.; Koono, E. and Beraquet, Y. (1999): Occurrence of Escherichia coli O157:H7 in hamburgers in Brazil. J. Food prot., 62: 1333-1335.

Slutsker, L.; Ries, A.A.; Maloney, K.; Wells, J.G.; Greene, K.D. and Griffin, P.M. (1988): A nationwide case-control study of Escherichia coli $\mathrm{O} 157: \mathrm{H} 7$ infection in the United States. J. Infection Diseases, 177:962-966.

Tafida, S.Y.; Kwaga, J.K.P.; Bello, M.; Kabir, J. ; Umoh, V.J.; Yakubu, S.E. and Nok, A.J. (2014): Occurrence of Escherichia coli 0157 in Retailed-Beef and Related Meat Products in Zaria, Nigeria. Food and Nutrition Sciences, 5: 481-487.

Varnam, A.H. and Evans, M.G. (1991): Food borne pathogens. An illustrated Textbook. Wolfe Publishing Ltd., New York: 209-234.

Williams, A.P.; Avery, L.M.; Killham, K. and Jones, D.L. (2005): Persistence of Escherichia coli O157 on farm surfaces under different environmental conditions. J. Applied Microbiol., 98: 1075-1083.

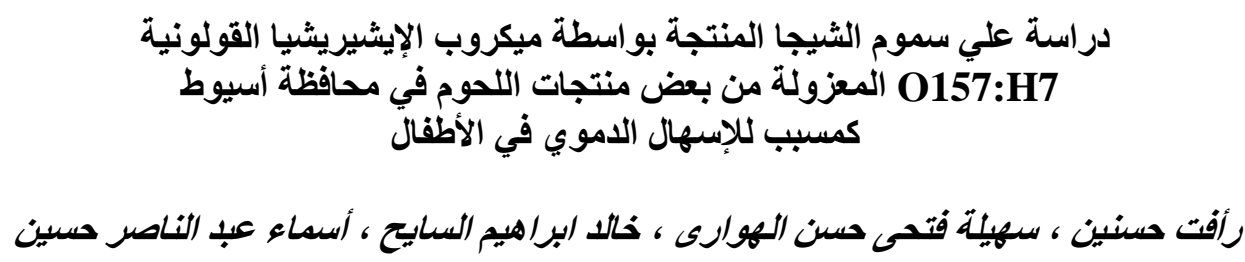

Email: sfhaae@yahoo.com Assiut University web-site: $\underline{\text { www.aun.edu.eg }}$

أجريت هذه الدر اسة على • ^ عينة (عشرون عينة من كل من البيف بيرجر المجمد، السجق المجمد ، ساندوتشات البيف بيرجر

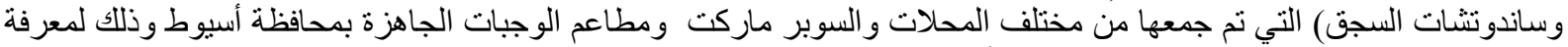

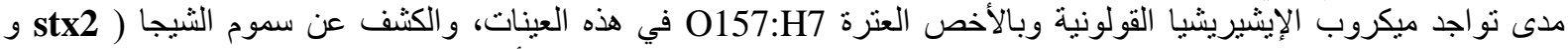

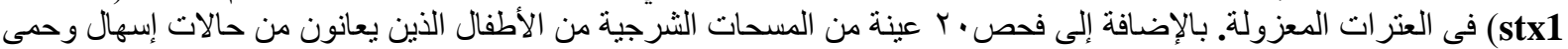

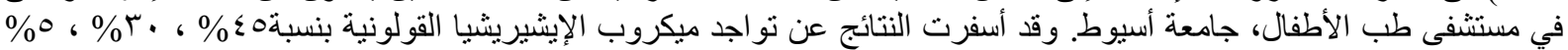

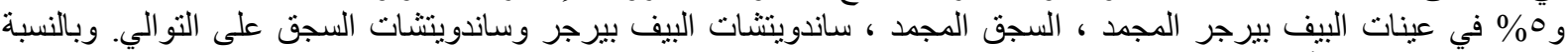

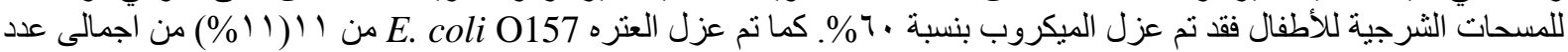

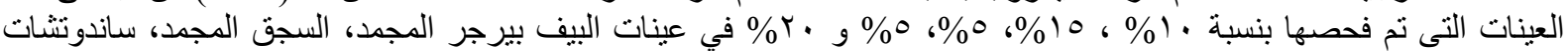

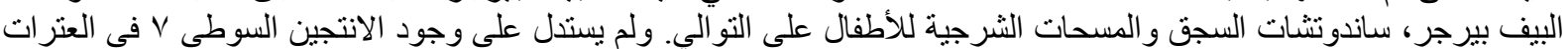

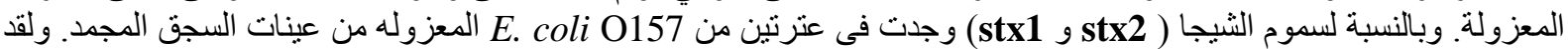
نو قتث الأهمية الصحية للميكروب وسمو مه ووضعت التوصيات اللازمة لسلامة المنتج و المستهلكئ. 